\title{
Association between the sitting posture and back pain in college students
}

\author{
Asociación entre la postura en sentado y el dolor \\ de espalda en estudiantes universitarios
}

\begin{abstract}
Aminta S Casas $\mathrm{S}^{1}$, María S Patiño $\mathrm{S}^{1}$, Diana M Camargo $\mathrm{L}^{1}$.
Suggested citation: Casas AS, Patiño MS, Camargo DM. Association between the sitting posture and back pain in college students. Rev Univ Ind Santander Salud. 2016; 48(4): 446-454. DOI: http://dx.doi.org/10.18273/revsal.v48n4-2016003 @) (1)
\end{abstract}

\begin{abstract}
Introduction: Back pain is a significant public health problem, its prevalence among college students is high, 30 - 70\%; Its association with the sitting position in workers has been reported, but its study in university populations is limited. Objective: To evaluate the association between sitting posture with back pain among college students. Methods: Cross-sectional study. Explanatory variables: sociodemographic characteristics, adequate lighting in the classroom, sitting posture and type of chair. Outcome variables: neck or back pain the day of the survey, acute and chronic. Logbinomial regression models estimated prevalence ratios (PR) and their 95\% CI. Results: 516 students from health deparment, age $21.3 \pm 2.6$ years, $69.2 \%$ women, $29,5 \%$ were in third year; $72,8 \%$ belong to middle socioeconomical level (3 and 4); and $18,4 \%$ of the students had an additional working activity. $87,8 \%$ of the classrooms had adequate lighting. Sitting posture with rounded back, feet supported on another chair and crossed legs was associated with neck pain the day of the survey (PR: 2.84), acute (PR: 2.41) and chronic (PR: 4.13). Other sitting posture with rounded back and crossed leg was associated with back pain the day of the survey (PR: 1.81) and acute (PR: 2.0). The screen time at the computer was associated with the outcome variables (PR 1.01 - 2.08). Conclusion: The results support the implementation of policies and institutional projects in order to prevent and control the back pain in college students.
\end{abstract}

Key words: neck pain, back pain, posture, students, human engineering.

\section{RESUMEN}

Introduccion: El dolor de espalda es un problema importante de salud pública, su prevalencia en estudiantes universitarios está entre el 30 al 70\%; su asociacion con la postura sentada en trabajadores ha sido reportada, pero en poblacion universitaria su estudio es limitado. Objetivo: Evaluar la asociación entre la postura en sentado con el dolor de espalda en estudiantes universitarios. Métodos: Estudio de corte transversal. Variables explicatorias: características sociodemográficas, iluminación del salón de clase, postura en sedente y tipo de silla. Variables de salida: dolor de cuello o espalda el día de la encuesta, agudo y crónico. Modelos de regresión log-binomial estimaron las razones de prevalencia (RP) y sus IC95\%. Resultados: Participaron 516 estudiantes de la facultad de salud, edad 21,3 $\pm 2,6$ años, $69,2 \%$ mujeres, $29,5 \%$ estaban en tercer año; y el 72,8\% pertenecía a los estratos socioeconómicos 3 y 4 , con un 18,4\% de los estudiantes, que además de estudiar desarrollaban actividades laborales. El 87,8\% de los salones de clase presentan iluminación adecuada. La postura en sedente con espalda redondeada, pies en otra superficie y pierna cruzada se asoció con dolor de cuello el día de la encuesta (RP: 2,84), agudo (RP: 2,41) y crónico

1. Universidad Industrial de Santander. Bucaramanga. Colombia.

Correspondence: Aminta Stella Casas Sánchez. Address: Facultad de Salud UIS. Carrera 32 Número 29-31. Bucaramanga, Santander, Colombia. E-mail: ascasas@uis.edu.co. Phone number+7 6344000, ext. 3147-3111. 
(RP: 4,13). Otra postura sentada con espalda redondeada y una pierna cruzada se asoció con dolor de espalda el día de la encuesta (RP: 1,81) y agudo (RP: 2,0). El tiempo en computador se asoció con las variables de salida (RP 1.01 - 2,08). Conclusión: Los resultados apoyan la implementación de políticas y proyectos institucionales dirigidos a prevenir y controlar el dolor de espalda en universitarios.

Palabras clave: Dolor de cuello, dolor de espalda, postura, estudiantes, ingeniería humana

\section{INTRODUCTION}

In public health back pain studies are important, because pain causes considerable personal discomfort, disability and impaired quality of life ${ }^{1,2}$. In addition, back pain has economic consequences due to increases healthcare costs, a decrease in productivity, additional sick leave, chronic disability for work, and ongoing occupational disability reimbursements $\mathrm{s}^{3,4}$.

Studies conducted with college students show a prevalence of back pain between $30 \%-70 \%$, depending on the time period analyzed, the anatomic region involved and the evolution time $e^{5-13}$. In the revised literature, the associations between pain and disability ${ }^{5}$, and the impact of pain on daily living activities have been found ${ }^{9}$. Cakmak A, et al. have reported a significant correlation between pain and disability $(\mathrm{r}=$ $0,405, \mathrm{P}=0.000)^{5}$ among college students with acute low back pain. Leggat $\mathrm{P}$, et al. reported impairment on daily living activities in $38.8 \%$ of the students; and $25 \%$ required pharmacological and/or alternative treatment ${ }^{9}$. The study of back pain in young people is important because this problem at an early age may be a risk factor for experience of pain in adulthood ${ }^{5,12}$.

Research on sitting posture and its association with back pain in college students is limited, there are no current estimates assessing the costs derivate from low back pain. Furthermore, to our knowledge, in Colombia there are no similar studies. The aim of this study was to evaluate the association between sitting posture with back pain in college students.

\section{METHODS}

A cross-sectional design in college students of both gender, enrolled in undergraduate academic programs of health (physical therapy, medicine, nursing, microbiology and nutrition) participated in the study between June and December 2009.

\section{Outcome Variables}

The back pain experience was measured by the Nordic Standardized-E Musculoskeletal Questionnaire (NMQ-E) adapted for this study, previously authorized by
Dr. Dawson ${ }^{14}$. The NMQ-E describes the pain experience in attributes as anatomic region (neck, dorsal and lower back), recall period (last 12 months, last 4 weeks and the day of the survey), evolution time (Acute $<4$ weeks, subacute $4-12$ weeks and chronic $>12$ weeks), intensity (visual analogue scale), limitation or inability to perform academic activities and treatments received for pain.

The NMQ-E was self-administered by 59 nursing students and reliability was examined using intraclass correlation coefficient (ICC). Overall, the results showed high reliability with mean ICC $=0.97(95 \%$ CI $=0,94-0,99)$ and ICC $=0,98(95 \% \mathrm{CI}=0,96-, 0,99)$; $0,87(95 \% \mathrm{CI}=0,70-0,95)$ and $0,98(95 \% \mathrm{CI}=0,96-$ $0,99)$ for neck, dorsal and low back respectively ${ }^{14}$.

\section{Explanatory variables}

Sociodemographic: Gender, age, socioeconomic level, undergraduate academic program, years at university, additional labor activity and time dedicated, were recorded. In addition, the weekly hours dedicated to academic activity, both inside and outside of the classroom were measured.

Characteristics of the chair and sitting time: We designed a self-report questionnaire based on the literature reviewed and related with ergonomic aspects of sitting posture ${ }^{15-18}$. The following variables were collected: type of chair used in the classroom with armrests, with a work desk and a laboratory bench; characteristics of the chair related with the back, width, depth, height of the chair and armrest, and adequate space between chairs ${ }^{16,19,20}$. The duration of sitting time (hours/day/week) and the classroom condition, related with light and temperature ${ }^{16}$, were also recorded.

Type of sitting posture: Based in the literature reviewed ${ }^{21-25}$ we established eight categories, described in Figure 1. The posture (C) was selected as the reference category for the analysis, because this position promotes the maintenance of physiological curvatures, the activation of the lumbar column stabilizing the musculature and the symmetrical distribution of the center of gravity, which can be considered the optimal sitting position ${ }^{21-26}$. We considered the other postures as possible risk factors for back pain. 


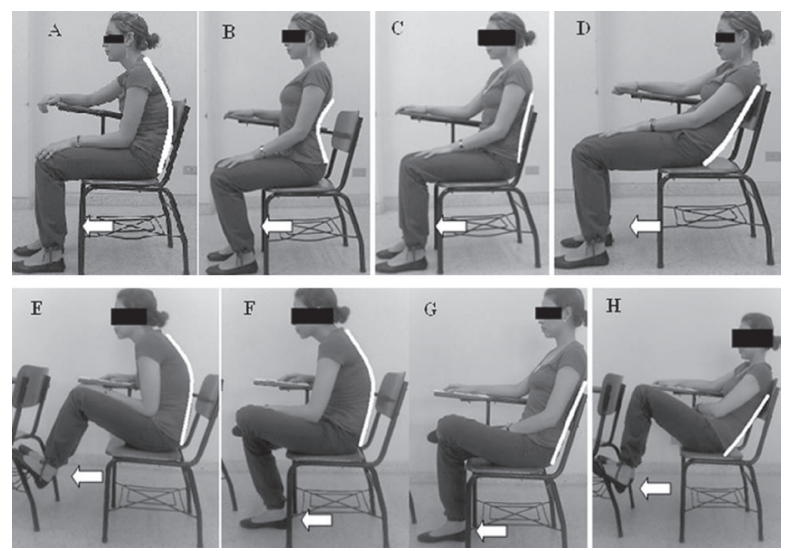

Figure 1. Sitting posture categories (A) Rounded back or increase of the kyphosis with the feet supported on the floor; (B) Increase of the lordosis and the feet supported on the floor; (C) Straight back and lumbopelvic control, with the feet supported on the floor; (D) Back support and reversion of the lumbar curvature, with the feet supported on the floor. (E) Rounded back or increase of the kyphosis, feet supported on another chair; (F) Rounded back or increase of the kyphosis and crossed leg; (G) Straight back and lumbopelvic control, crossed leg; (H) Back support and reversion of the lumbar curvature, with the feet supported on another chair.

\section{Procedure}

In a pilot test on 68 students, we established a mean time of 27 minutes to complete the questionnaire. The reliability of the questionnaire was then evaluated in two sessions with an interval of three days. The results showed Cohen's Kappa coefficients between 0.37 and 0.98 for experiencing pain and Intraclass Correlation Coefficients (ICC) ${ }^{27}$ between 0.68 and 0.99 for the sitting posture evaluation. These findings showed an acceptable reliability and a decrease in a potential misclassification bias of the outcome variables previously defined. Data was validated and analyzed in the software STATA $12.1^{28}$.

\section{Analysis}

Descriptive statistics tests based on each variable's distribution and nature were applied. Six dichotomous outcome variables were defined, according to the anatomical region with pain (neck and dorsal/lower back), evolution time: acute ( $<12$ weeks) and chronic $\geq 12$ weeks), as well as pain the day of the survey. Therefore, we generated six explanatory models for the multivariate analysis: (1) neck pain the day of the survey, (2) back pain the day of the survey, (3) acute neck pain, (4) chronic neck pain, (5) acute back pain and (6) chronic back pain. The group without pain was the reference category.

The main explanatory variable was the sitting posture adopted by the participant and the chair most frequently used (chair with armrests). Simple and multiple log- binomial regression models were applied ${ }^{29,30}$ to obtain unadjusted and adjusted prevalence ratios (PR), as well as their $95 \%$ confidence intervals, following Greenland's recommendations ${ }^{31}$. The female/gender was included in all models, in order to adjust the prevalence ratios obtained. Finally, the regression model adjustment was evaluated using the Link-test analysis, with a significance level at $\alpha=0.05$.

\section{RESULTS}

Five hundred and sixteen students, between June and December 2009 participated in the study; mean age $21.3 \pm 2.6$ years and $69.2 \%$ females. Almost $30 \%$ were in their third year of study, mainly from medical school $(42,6 \%)$; academic hours/week inside the classroom mean of $37.2 \pm 12.6$ and $24.2 \pm 13.9$ academic hours/ week outside classroom. The socioeconomic level more frequent was three and four $(72.8 \%)$. Ninetyfive students (18.4\%) work as employees, the most frequents were waiters, salespersons, nursing assistants, secretaries, and nannies, among other jobs, with a mean of $7.3 \pm 10.7$ work hours/week.

Pain: The results for pain experience showed an increase in the frequency when the recall period increases, the higher prevalence was obtained for neck pain $(79.8 \%)$. The pain experience showed similar intensities for the three anatomic regions (mean $4.1 \pm 2.07$ ); chronic pain was greater in the lower back region (45\%). The limitation in academic activities because of pain was between 22.7 and $29.8 \%$. Self-medication was the most frequent type of pain management Table 1.

Table 1. Back pain characteristics reported by participants the day of the survey.

\begin{tabular}{lccc}
\hline & \multicolumn{3}{c}{ Anatomic Region } \\
\cline { 2 - 4 } Characteristics of pain & $\begin{array}{c}\text { Neck } \\
\text { N (\%) }\end{array}$ & $\begin{array}{c}\text { Dorsal } \\
\text { N (\%) }\end{array}$ & $\begin{array}{c}\text { Lower back } \\
\text { N (\%) }\end{array}$ \\
\hline Recall period & & & \\
$\quad$ Last twelve months & $412(79.8)$ & $318(61.6)$ & $326(63.2)$ \\
$\quad$ Last four weeks & $348(67.4)$ & $261(50.6)$ & $247(47.9)$ \\
$\quad$ Day of the survey & $169(32.7)$ & $149(28.2)$ & $130(25.2)$ \\
Evolution time & & & \\
$\quad$ Acute (<4 weeks) & $59(35)$ & $51(34.2)$ & $41(31.8)$ \\
$\quad$ Sub-acute (4-12 weeks) & $41(23.8)$ & $45(30.2)$ & $30(23.3)$ \\
$\quad$ Chronic (>12 weeks) & $69(41.1)$ & $53(35.5)$ & $58(45.0)$ \\
Limitation in academic activities & $47(28.0)$ & $34(22.7)$ & $38(29.8)$ \\
Inability to perform & $11(6.5)$ & $3(2.0)$ & $5(3.9)$ \\
academic activities & $32(19.0)$ & $22(14.7)$ & $20(15.5)$ \\
Medical treatment & $20(11.8)$ & $19(12.7)$ & $21(16.3)$ \\
Physical therapy & $65(38.2)$ & $52(34.9)$ & $45(35.2)$ \\
Self-medication & & & \\
\hline
\end{tabular}


Sitting posture: The sitting time in classroom activities (mean $21 \pm 8.5$ hours/week) was similar to independent academic activities (mean 20.7 \pm 12.7 hours/week); the computer screen time was $17.9 \pm 12$ hours/week. A chair with armrests was used most frequently $(88.4 \%)$, and the $\mathrm{H}(31.6 \%)$ and $\mathrm{D}(27.2 \%)$ postures were adopted principally Figure 1.

The students reported that chair characteristics were adequate except for the back (57\%) and high of the armrest (86.6\%). The classroom conditions were adequate for lighting $(87.8 \%)$, but the temperature was hot $(40 \%)$.

In this study, the chair with armrests only offered comfort to $57 \%$ of the participants, for $8 \%$, the armrest was located on the side opposite of dominant hand for writing, and for $13.4 \%$, the armrest height did not align with the elbow level. The seat did not allow for placement/positioning of the hips and thighs for $12.3 \%$ of participants, and for $3.5 \%$ the height of the chair did not allow the full support of the feet on the floor.

\section{Multivariate analysis}

\section{Factors associated with neck and back pain the day of the survey.}

The unadjusted and adjusted prevalence ratios and their respective $95 \%$ confidence intervals are shown in Table 2. The female gender was associated with neck and back pain the day of the survey, with $\mathrm{PR}=$ 1.42 and 1.37 , respectively. In addition, time in front of computer $\geq 21$ hours/week registered for neck pain $(P R=1.39)$ and for back pain $(P R=1.42)$. Sitting postures with a rounded back or increased kyphosis and feet supported on another chair (E) and with a rounded back or increase in kyphosis with legs crossed $(\mathrm{F})$ were associated with neck pain $(\mathrm{PR}=2.84)$ and back pain $(\mathrm{PR}=1.81)$. The level of lighting in the classroom was negatively associated with neck pain $(\mathrm{PR}=0.66)$, while the adequate positioning of the hip and thigh on the seat was negatively associated $(\mathrm{PR}=$ 0.72 ) with back pain.

Table 2. Factors associated with neck pain and back pain the day of the survey (N: 410 observations, Link-test 0.30 for neck pain. N: 456 observations, Link-test 0.79 for back pain).

\begin{tabular}{|c|c|c|c|c|c|c|}
\hline Factor & $\mathbf{P R}^{\mathrm{a}}$ & $95 \% \mathrm{CI}$ & $\mathbf{p}$ & $\mathbf{P R}^{\mathbf{b}}$ & $95 \% \mathrm{CI}$ & $\mathbf{P}$ \\
\hline \multicolumn{7}{|l|}{ Neck pain } \\
\hline Female gender & 1.48 & $1.09-2.01$ & 0.011 & 1.42 & $1.04-1.95$ & 0.026 \\
\hline Age $\geq 27$ years & 1.45 & $1.07-1.98$ & 0.017 & 1.48 & $1.12-1.96$ & 0.006 \\
\hline \multicolumn{7}{|l|}{ Sitting posture $^{c}$} \\
\hline $\mathrm{C}$ & 1.0 & & & 1.0 & & \\
\hline $\mathrm{E}, \mathrm{F}$ & 2.41 & $1.31-4.43$ & 0.005 & 2.84 & $1.62-4.97$ & $<0.0001$ \\
\hline $\mathrm{A}, \mathrm{B}, \mathrm{D}, \mathrm{G}, \mathrm{H}$ & 1.24 & $0.71-2.18$ & 0.44 & 1.32 & $0.75-2.33$ & 0.33 \\
\hline Screen time in computer $\geq 21 \mathrm{~h} / \mathrm{w}$ & 1.41 & $1.09-1.83$ & 0.009 & 1.39 & $1.14-1.70$ & 0.001 \\
\hline $\begin{array}{l}\text { Adequate lighting } \\
\text { in the classroom }\end{array}$ & 0.64 & $0.49-0.87$ & 0.003 & 0.66 & $0.54-0.81$ & $<0.0001$ \\
\hline \multicolumn{7}{|l|}{ Back pain } \\
\hline Female gender & 1.43 & $1.12-1.81$ & 0.004 & 1.37 & $1.07-1.75$ & 0.011 \\
\hline \multicolumn{7}{|l|}{ Sitting posture ${ }^{c}$} \\
\hline $\mathrm{C}$ & 1.0 & & & 1.0 & & \\
\hline $\mathrm{F}$ & 1.68 & $1.04-2.69$ & 0.033 & 1.81 & $1.14-1.74$ & 0.001 \\
\hline A, B, D, E, G, H. & 1.09 & $0.73-1.63$ & 0.66 & 1.15 & $0.79-1.66$ & 0.472 \\
\hline Work /employment & 1.25 & $1.01-1.55$ & 0.039 & 1.45 & $1.16-1.82$ & 0.003 \\
\hline Screen time in computer $\geq 21 \mathrm{~h} / \mathrm{w}$ & 1.36 & $1.12-1.66$ & 0.002 & 1.42 & $1.15-1.75$ & 0.001 \\
\hline $\begin{array}{l}\text { Hip and thigh on the seat } \\
\text { Adequate positioning. }\end{array}$ & 0.73 & $0.57-0.94$ & 0.016 & 0.72 & $0.55-0.90$ & 0.009 \\
\hline
\end{tabular}

a Unadjusted ${ }^{\mathrm{b}}$ Adjusted

c Type of posture seated chair on the chair with armrests: A) Seated with a rounded back or an increase in kyphosis, with the feet placed on the floor. (B) Seated with an increase in lordosis and with the feet placed on the floor. (C) Seated with a straight back and lumbopelvic control, with the feet supported on the floor - reference category. (D) Seated with upper back support lumbar curvature reversion, with feet planted on the floor. (E) Seated with a rounded back or an increase in kyphosis, feet planted on another chair. (F) Seated with a rounded back or an increase in kyphosis and legs crossed. (G) Seated with a straight back and lumbopelvic control and legs crossed. $(\mathrm{H})$ Seated with upper back support and lumbar curvature reversion, with feet planted on another chair. 
Factors associated with chronic and acute neck pain

Acute and chronic neck pain was positively associated with female gender, with $\mathrm{PR}=1.59$ and $\mathrm{PR}=1.48$, respectively. In addition, sitting postures with a rounded back or increased kyphosis and the feet supported on another chair (E) and sitting with a rounded back or increased kyphosis and one crossed leg $(\mathrm{F})$ were positively associated $\mathrm{PR}=2.41$ and $\mathrm{PR}=4.13$, respectively. The increase in computer screen time was positively associated with chronic neck pain (PR between 1.61 and 1.71). Only the level of lighting in the classroom shows a negative association with chronic neck pain $(\mathrm{PR}=0.34)$ Table 3 .

Table 3. Factors associated with acute and chronic neck pain. (N: 396 observations, Link-test $=0.74$ acute neck pain. N: 346 observations, Link-test $=0.6$ chronic neck pain).

\begin{tabular}{|c|c|c|c|c|c|c|}
\hline Factor & $\mathbf{P R}^{\mathbf{a}}$ & $95 \% \mathrm{CI}$ & $\mathbf{P}$ & $\mathbf{P R}^{\mathbf{b}}$ & $95 \% \mathrm{CI}$ & $\mathbf{P}$ \\
\hline \multicolumn{7}{|l|}{ Acute neck pain } \\
\hline Female gender & 1.73 & $1.12-2.69$ & 0.014 & 1.59 & $1.02-2.51$ & 0.04 \\
\hline \multicolumn{7}{|l|}{ Sitting posture $^{\mathrm{c}}$} \\
\hline $\mathrm{C}$ & 1.0 & & & 1.0 & & \\
\hline$E$ and $F$ & 2.57 & $1.07-6.15$ & 0.034 & 2.41 & $1.03-5.69$ & 0.04 \\
\hline $\mathrm{A}, \mathrm{D}, \mathrm{G}, \mathrm{H}$ & 1.29 & $0.60-2.76$ & 0.51 & 1.25 & $0.59-2.69$ & 0.55 \\
\hline Computer screen time $\geq 21 \mathrm{~h} / \mathrm{w}$ & 1.01 & $1.00-1.02$ & 0.01 & 1.01 & $1.001-1.024$ & 0.007 \\
\hline \multicolumn{7}{|l|}{ Chronic neck pain } \\
\hline Female gender & 1.40 & $0.86-2.32$ & 0.17 & 1.48 & $0.89-2.48$ & 0.13 \\
\hline \multicolumn{7}{|l|}{ Sitting posture ${ }^{c}$} \\
\hline $\mathrm{C}$ & 1.0 & & & 1.0 & & \\
\hline $\mathrm{E}$ and $\mathrm{F}$ & 3.64 & $1.29-10.28$ & 0.014 & 4.13 & $1.56-10.92$ & 0.004 \\
\hline $\mathrm{A}, \mathrm{D}, \mathrm{G}, \mathrm{H}$ & 1.29 & $0.49-3.38$ & 0.59 & 1.31 & $0.50-3.47$ & 0.58 \\
\hline \multicolumn{7}{|l|}{ Computer Screen time $(\mathrm{h} / \mathrm{w})$} \\
\hline $1-11$ & 1.0 & & & 1.0 & & \\
\hline $12-20$ & 1.42 & $0.78-2.60$ & 0.25 & 1.61 & $1.06-2.45$ & 0.02 \\
\hline $21-96$ & 1.96 & $1.10-3.48$ & 0.02 & 1.71 & $1.13-2.61$ & 0.01 \\
\hline Adequate lighting in classroom & 0.41 & $0.27-0.63$ & $<0.0001$ & 0.34 & $0.23-0.50$ & $<0.0001$ \\
\hline
\end{tabular}

${ }^{a}$ Unadjusted ${ }^{\mathrm{b}}$ Adjusted

${ }^{c}$ Type of sitting posture in a chair with armrests: A) Seated with a rounded back or an increase in kyphosis, with feet planted on the floor. (B) Seated with an increase in lordosis and with feet planted on the floor. (C) Seated with a straight back and lumbopelvic control, with feet planted on the floor - reference category. (D) Seated with upper back support and lumbar curvature reversion, with feet supported on the floor. (E) Seated with a rounded back or an increase in kyphosis, feet supported on another chair. (F) Seated with a rounded back or an increase in kyphosis and legs crossed. (G) Seated with a straight back and lumbopelvic control and legs crossed. (H) Seated with upper back support and lumbar curvature reversion, with feet supported on another chair.

\section{Factors associated with acute and chronic back pain}

The Table 4 shows the prevalence ratios with positive associations for female gender, both acute and chronic back pain, $\mathrm{PR}=1.63$ and $\mathrm{PR}=1.68$, respectively. The sitting posture with a rounded back or increased kyphosis and the legs crossed (F) was associated with acute back pain $(\mathrm{PR}=2.0)$, whereas the sitting posture with upper back support and lumbar strain, with the feet supported on the floor (D), was positively associated with chronic back pain $(\mathrm{PR}=1.61)$. Similarly, computer screen time $\geq 21$ hours/week was associated with acute and chronic back pain ( $\mathrm{PR}=$ 1.45 and $\mathrm{PR}=2.08$ ), respectively. Positioning the hip and thigh in the seat were negatively associated with acute back pain $(\mathrm{PR}=0.61)$. 
Salud Vol.48 No.4 Octubre - Diciembre de 2016

DOI: http://dx.doi.org/10.18273/revsal.v48n4-2016003

Table 4. Factors associated with acute and chronic back pain. (N: 378 observations, Link-test $=0.49$ for acute back pain. N: 335 observations, Link-test: 0.63 for chronic back pain).

\begin{tabular}{|c|c|c|c|c|c|c|}
\hline Factor & $\mathbf{P R}^{\mathrm{a}}$ & $95 \%$ CI & $\mathbf{P}$ & $\mathbf{P R}^{\mathrm{b}}$ & $95 \%$ CI & $\mathbf{p}$ \\
\hline \multicolumn{7}{|l|}{ Acute back pain } \\
\hline Female gender & 1.66 & $1.17-2.35$ & 0.004 & 1.63 & $1.15-2.32$ & 0.005 \\
\hline \multicolumn{7}{|l|}{ Sitting posture } \\
\hline $\mathrm{C}$ & 1.0 & & & 1.0 & & \\
\hline $\mathrm{F}$ & 2.23 & $1.15-4.32$ & 0.017 & 2.0 & $1.10-3.61$ & 0.021 \\
\hline $\mathrm{A}, \mathrm{B}, \mathrm{D}, \mathrm{E}, \mathrm{G}, \mathrm{H}$ & 1.16 & $0.65-2.08$ & 0.061 & 1.08 & $0.63-1.89$ & 0.764 \\
\hline Screen computer time $\geq 21 \mathrm{~h} / \mathrm{w}$ & 1.39 & $1.04-1.87$ & 0.026 & 1.45 & $1.09-1.92$ & 0.009 \\
\hline $\begin{array}{l}\text { Hip and thigh on the seat } \\
\text { Adequate positioning. }\end{array}$ & 0.66 & $0.46-0.96$ & 0.027 & 0.61 & $0.47-0.81$ & 0.001 \\
\hline \multicolumn{7}{|l|}{ Chronic back pain } \\
\hline Female gender & 1.42 & $0.95-2.14$ & 0.048 & 1.68 & $1.12-2.51$ & 0.011 \\
\hline \multicolumn{7}{|l|}{ Sitting posture ${ }^{\mathrm{c}}$} \\
\hline $\mathrm{C}$ & 1.0 & & & 1.0 & & \\
\hline D & 1.30 & $0.63-2.71$ & 0.47 & 1.61 & $0.92-2.81$ & 0.095 \\
\hline $\mathrm{A}, \mathrm{B}, \mathrm{E}, \mathrm{F}, \mathrm{G}, \mathrm{H}$ & 0.97 & $0.48-1.96$ & 0.93 & 0.88 & $0.52-1.72$ & 0.884 \\
\hline Work /employment & 1.51 & $1.03-2.22$ & 0.03 & 2.24 & $1.66-3.02$ & $<0.0001$ \\
\hline Screen computer time $\geq 21 \mathrm{~h} / \mathrm{w}$ & 1.67 & $1.17-2.39$ & 0.005 & 2.08 & $1.51-2.84$ & $<0.0001$ \\
\hline
\end{tabular}

anadjusted, ${ }^{\mathrm{b}}$ Adjusted

'Type of sitting posture in a chair with an armrest: A) Seated with a rounded back or an increase in kyphosis, with feet supported on the floor. (B) Seated with an increase in lordosis and with feet supported on the floor. (C) Seated with a straight back and lumbopelvic control, with feet supported on the floor - reference category. (D) Seated with upper back support and lumbar curvature reversion, with feet supported on the floor. (E) Seated with a rounded back or an increase in kyphosis, feet supported on another chair. (F) Seated with a rounded back or an increase in kyphosis and legs crossed. (G) Seated with a straight back and lumbopelvic control and one leg crossed. (H) Seated with upper back support and lumbar curvature reversion, with feet supported on another chair.

\section{DISCUSSION}

This study provides evidence related to the association between the sitting posture and back pain in college students, which represent the main academic activity during their professional training, both inside and outside of the classroom.

The prevalence data obtained from this study Table 1 is similar to the data reported in previous publications ${ }^{5-13}$. The increasing prevalence with the recall period was previously documented by Camargo DM, et al. $(2009)^{12}$, besides similar prevalence the day of the survey $(34.2 \%)$ for acute pain $(18.3 \%)$ and chronic pain $(22.8 \%)$. These data supports the evidence of back pain as a public health problem among college students.

The moderate intensity registered in all anatomic regions (mean closer to 4.0) and the prevalence of limitation for academic activities (almost 30\%) suggests their implication on the daily life activities and a potential effect on the students' life quality. Leggat PA, et al. $(2008)^{9}$ found that low back pain affects daily activities to $38.8 \%$ of the students; furthermore,
$25 \%$ require some type of treatment. Additionally, the study by Cakmak A, et al. (2004) $)^{5}$ revealed a significant but moderate correlation between pain severity and disability $(\mathrm{r}=0.405 ; \mathrm{p}=0.000)$.

\section{Sitting Posture}

It is recognized that proper posture keeps the spinal curved while in the seated position, but when the spine's normal curvatures are reduced or accentuated, stress in the ligamentous structures is produced and may potentially produce pain ${ }^{32}$. The sitting posture is determined by several factors including: the workplace design, the characteristics of the chair and desk, the visual and manual requirements of the occupational task, environmental factors such as room temperature and lighting as well as the individual anatomical and anthropometric characteristics.

Another important factor is the time spent sitting, because most of the academic activities are conducted in this position. This factor demonstrated that the time invested in academic activities both, inside the classroom $(21 \pm 8.5$ hours/week) or outside $(20.7 \pm$ 
12.7 hours/week) and computer screen time (17.9 \pm 12 hours/week) are associated with acute and chronic neck and back pain the day of the survey Tables $2-4$.

These associations have been previously reported to college students. Leggat PA, et al. (2008) ${ }^{9}$ found that the computer screen time lapses between 16-20 hours/ week were associated with low back pain $(\mathrm{OR}=5.5$; 95\%CI: 1.1 - 33.1). Likewise, Grimby- Ekman A, et al. $(2009)^{13}$ showed that the number of times/week, that the computer is used for $\geq 4$ hours/day without a break is positively associated to neck pain $(\mathrm{OR}=1.7 ; 95 \% \mathrm{CI}$ : 0.94-2.94). Boström M, et al. (2008) ${ }^{33}$ also found this association in subjects who used the computer 8-14 hours/week during their free time $(\mathrm{PR}=2.3 ; 95 \% \mathrm{CI}$ : 1.20-4.5).

Chiu TT, et al. (2002) $)^{34}$ and Burgess-Limerick K. et al. $(1999)^{35}$ have discussed the association between head positioning during computer screen time and neck pain. However, according to these studies, there is not enough evidence to recommended computer screen height, or the posture adopted for laptop computers, which are currently widely used.

It is important to clarify that the sitting posture adopted for computer work was not analyzed in the present work. We have studied classroom sitting specifically. However, it is important to analyze computer posture very carefully in a future study, given the associations between this factor to neck and low back pain.

Regarding the type of sitting posture, it was found that $88.4 \%$ of the participants used chairs with armrests. On this type of chair, two positions (rounded back or increased kyphosis and the feet supported on another chair (E) and sitting with a rounded back or increased kyphosis and the legs crossed (F) were identified as significant and positively associated to neck pain the day of the survey $(\mathrm{PR}=2.84)$, as well as acute $(\mathrm{PR}=$ 2.41) and chronic pain $(\mathrm{PR}=4.1)$ Tables 2 and 3.

Ariëns GAM, et al. (2001) $)^{36}$ found similar results between the sitting posture times and neck pain (RR $=2.01)$. Likely, an increased risk among people who work with a minimum neck flexion of 20 degrees for more than $70 \%$ of the workday in this position was reported $(\mathrm{RR}=2.0)$.

These associations can be explained due to the back rounded position with increased kyphosis in the postures $\mathrm{E}$ and $\mathrm{F}$. In these positions the electrical activity of the neck muscles and spinal erectors are increased, as well as pressure on the cervical spine. Postures $\mathrm{E}$ and $\mathrm{F}$ also decreases cervical lordosis, increase nerve roots tension and intervertebral disk pressure, contributing neck pain factors ${ }^{21}$.

However, position $\mathrm{F}$ also showed a significant and positive association with back pain the day of the survey $(\mathrm{PR}=1.81)$ and acute back pain $(\mathrm{PR}=2.0)$.In fact, Nyland LJ, and Grimmer KA $(2003)^{8}$ reported that the position with neck flexion and increased kyphosis (i.e., " looking down") sustained for more than 20 hours during the previous month was significantly associated to lower back pain $(\mathrm{OR}=2.4)$.

In this study, posture $\mathrm{D}$ was associated to chronic back pain $(\mathrm{PR}=1.61)$. In contrast to previous postures, staying seated in posture D with upper back support and lumbar strain with feet on the floor, can generate intermittent pain associated to the prolonged sitting posture and related to sedentary youth ${ }^{37,38}$.

Additionally, we established that adequate dimensions of the chair seat were negatively associated with back pain the day of the survey $(\mathrm{PR}=0.72)$ and acute back pain $(P R=0.61)$ (Tables 2 and 4). Similar relationships have been documented between some characteristics of the chair such as back support, seat dimensions, armrest height with to intervertebral disk pressure, the spinal muscle electric activity and pelvic position ${ }^{16,21}$.

In this study, the findings of discomfort associated to the dimensions of the chair demonstrate the need to formulate and implement student furniture replacement policies in order to provide seats compatible with the students' anthropometric characteristics. Maradei MF, et al. $(2009)^{20}$ proposed anthropometric tables designs that can help the decision making process on appropriate dimensions for student's furniture.

The classroom conditions showed that adequate lighting diminishes neck pain the day of the survey (PR 0.66) and chronic neck pain ( $P R=0.34)$. Although, $87.7 \%$ of the participants assessed the lighting level as adequate. The importance of the lighting factor is crucial to maintain and improve classroom conditions in order to avoid postural alterations related to vision ${ }^{16}$.

This importance of this study relies on its contribution to support evidence regarding sitting posture as a risk factor for neck and back pain in college students, which will be the basis to propose and to develop integral intervention strategies. The sample size and the logbinomial regression analysis applied to evaluate the 
associations constitutes the strength in our study, because the Odds Ratio obtained by logistic regression analysis, overestimates the associations when the prevalence of the events are high, as neck and back pain analyzed in this study ${ }^{39}$.

Among the limitations of this study, we mention a potential misclassification bias represented by information collected by questionnaires, which generally tend to register socially desirable behaviors. Additionally, the cross-sectional design does not allow for the identification of etiological factors, only epidemiological associations. However, the associations presented herein have been documented previously with scientific evidence and biological plausibility.

Finally, the importance of muscle skeletal pain research in young people should not be underestimated. It can help to predict pain in adulthood, when the impact on functionality, daily activities and quality of life is higher. In addition, it is important to consider that the studied population are from the health school programs. These students study to have an extensive and integral knowledge of pain management for application not only in their own lives but also for the care of their patients ${ }^{12}$.

It is worthwhile to consider the importance of interdisciplinary work between different healthcare professions such as physical therapy, medicine, nursing, nutrition and psychology, among others, to achieve significantly contributing to prevention and control of pain from school-aged children to adulthood ${ }^{12}$.

\section{ETHICAL CONSIDERATIONS}

University of Antioquia's ethical committee approved the study (Code 037/09) and Santander Industrial University's ethical committee (Code SP09038). All participants signed the informed consent form before the survey administration.

\section{REFERENCES}

1. Ehrlich GE. Low back pain. Bull World Health Organ. 2003; 81(9): 671-676.

2. Hurwitz EL, Morgenstern H. Correlates of back problems and back-related disability in the United States. J Clin Epidemiol. 1997; 50(6): 669-681.

3. National Institute for Occupational Safety and Health. Low-back musculoskeletal disorders. In: National Institute for Occupational Safety and Health. Musculoskeletal disorders and workplace factors: A critical review of epidemiologic evidence for work-related musculoskeletal disorders of the neck upper extremity and low back. 2. ed. Cincinnati: National Institute for Occupational Safety and Health; 1997.p.6-1 - 6-96.

4. Wenig CM, Schmidt CO, Kohlmann T, Schwikert B. Cost of back pain in Germany. Eur J Pain. 2009; 13(3): 280-286. DOI: 10.1016/j.ejpain.2008.04.005.

5. Cakmak A, Yücel B, Ozyalçn SN, Bayraktar B, Ural HI, Duruöz MT, et al. The frequency and associated factors of low back pain among a younger population in Turkey. Spine. 2004; 29(14): 1567-1572.

6. Smith DR, Leggat PA. Prevalence and distribution of musculoskeletal pain among australian medical students. J Musculoskelet Pain. 2007; 15(4): 39-46. DOI: 10.1300/J094v15n04_05.

7. Smith DR, Wei N, Ishitake $T$, Wang R. Musculoskeletal disorders among Chinese medical students. Kurume Med J. 2005; 52: 139-146.

8. Nyland LJ, Grimmer KA. Is undergraduate physiotherapy study a risk factor for low back pain? A prevalence study of LBP in physiotherapy students. BMC Musculoskelet Disord. 2003; 4: 22. DOI: 10.1186/1471-2474-4-22.

9. Leggat PA, Smith DR, Clark MJ. Prevalence and correlates of low back pain among occupational therapy students in Northern Queensland. Can J Occup Ther. 2008; 75(1): 35-41.

10. Smith DR, Leggat PA. Musculoskeletal disorders among rural Australian nursing students. Aust J Rural Health. 2004; 12(6): 241-245. DOI: 10.1111/j.1440-1854.2004.00620.x.

11. Mitchell T, O'Sullivan PB, Burnett AF, Straker L, Rudd C. Low back pain characteristics from undergraduate student to working nurse in Australia: A cross-sectional survey. Int $\mathrm{J}$ Nurs Stud. 2008; 45(11): 1636-1644. DOI: 10.1016/j. ijnurstu.2008.03.001.

12. Camargo DM, Orozco LC, Hernández J, Niño GI. Dolor de espalda crónico y actividad física en estudiantes de áreas de la salud. Rev Soc Esp Dolor. 2009; 16(8): 429-436.

13. Grimby-Ekman A, Andersson EM, Hagberg M. Analyzing musculoskeletal pain, measured as present pain and periods of pain with three different regression models: a cohort study. BMC Musculoskelet Disorders. 2009; 10(73): 1-11. DOI: 10.1186/1471-2474-10-73.

14. Dawson AP, Steele EJ, Hodges PW, Stewart S. Development and test-retest reliability of an extended version of the Nordic Musculoskeletal Questionnaire. (NMQ-E): a screening instrument for musculoskeletal pain. J Pain. 2009; 10(5): 517526. DOI: 10.1016/j.jpain.2008.11.008. 
15. Makhsous M, Lin F, Hendrix RW, Hepler M, Zang LQ. Sitting with adjustable ischial and back supports: biomechanical Changes. Spine. 2003; 28(11): 11131122. DOI: $10.1097 / 01 . B R S .0000068243 .63203$.A8.

16. Bridger RS. Static work: design for standing and seated workers. In: Bridger RS. Introduction to ergonomics. 3. ed. New York: Taylor \& Francis Group; 2008. p.89-120.

17. Smith ER. Seating. In: Jacobs K. Ergonomics for Therapists. 3. ed. St. Louis: Mosby Inc; 2008. p.191-220.

18. García C, Moraga R, Page A, Tortosa L, Verde V. Guía de recomendaciones para el diseño de mobiliario ergonómico. Instituto de Biomecánica de Valencia. Valencia: Artes Gráficas Beracrom SL; 1.992.

19. Vergara M, Page A. Relationship between comfort and back posture and mobility in sitting-posture. Appl Ergon. 2002; 33(1): 1-8.

20. Maradei MF, Espinel FM, Peña AA. Datos antropométricos para el diseño. Bucaramanga: Publicaciones UIS; 2009.

21. Harrinson DD, Harrinson SO, Croft AC, Harrinson DE, Troyanovich SJ. Sitting biomechanics part I: Review of the literature. J Manipulative Physiol Ther. 1999; 22(9): 594-609.

22. Claus AP, Hides JA, Moseley GL, Hodges PW. Is "ideal" sitting posture real?: Measurement of spinal curves in four sitting postures. Man Ther. 2009; 14(4): 404 -408. DOI: 10.1016/j.math.2008.06.001.

23. O'Sullivan PB, Grahamslaw KM, Kendell M, Lapenskie SC, Möller NE, Richards KV. The effect of different standing and sitting postures on trunk muscle activity in a pain-free population. Spine. 2002; 27(11): 1238-1244.

24. O'Sullivan PB, Dankaerts W, Burnett AF, Farrell GT, Jefford E, Naylor CS, et al. Effect of different upright sitting postures on spinal pelvic curvature and trunk muscle activation in a pain free population. Spine. 2006; 31(19): E707-712. DOI: 10.1097/01. brs.0000234735.98075.50.

25. Mitchell T, O'Sullivan PB, Burnett AF, Straker L, Smith A. Regional differences in lumbar spinal posture and the influence of low back pain. BMC Musculoskeletal Disorders. 2008; 9:152. DOI: 10.1186/1471-2474-9-152.

26. Pope MH. Clinical Biomechanics of the Spine. In: Nordin M, BJ, Andersson GBJ. Pope MH. Musculoskeletal disorders in the workplace: Principles and practice. St Louis: Editorial Mosby; 1997. p. $269-276$.

27. Streiner DL, Norman GR. Health Measurement Scales: a practical guide to their development and use. 3. ed. New York: Oxford University Press; 2003.

28. StataCorp. Stata Statistical Software. Release 12. College Station, TX: StataCorp LP; 2011.

29. Pagano M. Principles of biostatistics. Belmont: Duxbury Press; 1993.

30. Wacholder S. Binomial Regression in GLIM: Estimating risk radios and risk differences. Am J Epidemiol. 1986; 123(1): 174-184.

31. Greenland S. Modeling and variable selection in epidemiologic analysis. Am J Public Health. 1989; 79(3): 340-349.

32. Kendall F, Kendall E, Provance P. Actitud postural: alineamiento y equilibrio muscular. En: Kendall F, Kendall E, Provance P. Kendall's: Músculos: Pruebas, funciones y dolor postural. 4. ed. Madrid: Marban; 2000.p. 69-117.

33. Boström M, Dellve L, Thomée S, Hagberg M. Risk factors for generally reduced productivity-a prospective cohort study of young adults with neck pain or upper-extremity musculoskeletal symptoms. Scand J Work Environ Health. 2008; 34(2): 120132.

34. Chiu TT, Ku WY, Lee MH, Sum WK, Wan MP, Wong CY, et al. A Study on the prevalence of and risk factors for neck pain among university academic staff in Hong Kong. J Occup Rehabil. 2002; 12 (2): 77-91.

35. Burgess-Limerick K, Plooy A, Fraser K, Ankrum DR. The influence of computer monitors height on head and neck posture. Int J Ind Ergon. 1999; 23: 171-179.

36. Ariëns G, Bongers P, Douwes $M$, Miedema $M$, Hoogendoorn W, Van der Wal G, et al. Are neck flexion, neck rotation, and sitting at work risk factors for neck pain? Results of a prospective cohort study. Occup Environ Med. 2001; 58(3): 200-207. DOI: 10.1136/oem.58.3.200.

37. Magnusson M. Posture. In: Nordin M, Andersson GBJ, Pope MH. Musculoskeletal disorders in the workplace: Principles and practice. St Louis: Editorial Mosby; 1997. p.74-84.

38. Lord MJ, Small JM, Dinsay JM, Watkins RG. Lumbar lordosis: Effects of sitting and standing. Spine. 1997; 22(21): 2571-2574.

39. Zocchetti C, Consonni D, Bertazzi PA. Relationship between prevalence rate ratios and odds ratios in cross-sectional studies. Int J Epidemiol. 1997; 26: 220-223. 